\title{
Menghardik Halusinasi: Jurnal refleksi
}

\section{Febri Warni Hulu}

\section{febriwarnihulu@gmail.com}

Thanks a lot to God, karena saya mampu menerapkan terapi menghardik pada pasien. Saya sangat bersyukur dan merasa puas atas kemampun saya untuk melakukan terapi menghardik pada pasien dengan halusinasi. Meskipun awalnya ragu dalam melakukan terapi ini, namun saya berhasil melewatinya, meski saya jarang melakukan terapi ini, dimana biasanya saya hanya belajar dengan sesama teman, namun ada kebanggaan bagi saya dapat menerapkan terapi ini secara langsung kepada pasien dengan baik.

Halusinasi merupakan keadaan seseorang mengalami perubahan dalam pola dan jumlah stimulasi yang diprakarsai secara internal atau eksternal disekitar dengan pengurangan berlebihan, distorsi, atau kelainan berespon terhadap setiap stimulasi dan halusinasi juga merupakan perubahan dalam jumlah dan pola dari stimulasi yang diterima dan disertai dengan penurunan berlebihan distorsi atau kerusakan respon beberapa stimulasi. (Pardede, 2016).

Faktor-faktor yang mampu mempengaruhi kekambuhan penderita skizofrenia dengan halusinasi meliputi ekspresi emosi keluarga yang tinggi, pengetahuan keluarga yang kurang, ketersediaan pelayanan kesehatan, penghasilan keluarga dan kepatuhan minum obat pasien skizofrenia. (Pardede, 2020). Menghardik halusinasi adalah upaya mengendalikan diri terhadap halusinasi dengan cara menolak halusinasi yang muncul. Pasien dilatih untuk mengatakan tidak terhadap halusinasi yang muncul atau tidak memerdulikan halusinasinya. (Umam, 2015) Suatu kebanggan bagi saya dapat menerapkan terapi ini, saya berharap semoga ilmu yang saya dapat ini menjadi bekal yang berharga bagi saya kedepannya. 


\section{REFERENSI}

Pardede, J. A. (2020). Beban Keluarga Berhubungan Dengan Koping Saat Merawat Pasien Halusinasi. Jurnal Ilmu Keperawatan Jiwa, 3(4), 445-452.

Pardede, J. A., \& Siregar, R. A. (2016). Pendidikan Kesehatan Kepatuhan Minum Obat Terhadap Perubahan Gejala Halusinasi Pada Klien skizofrenia. Mental Health, 3(1).

Umam, R. (2015). Pelaksanaan Teknik Mengontrol Halusinasi: Kemampuan Klien Skizofrenia Mengontrol Halusinasi. The Sun, 2(1). 
